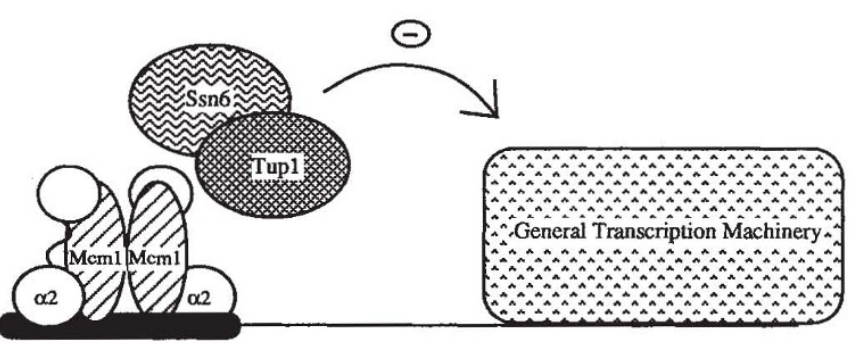

FIG. 4 Model for transcriptional repression by the yeast $\alpha 2$ protein.

(Fig. 4). These in vitro transcription reactions include no exogenously added activator protein, nor does the DNA template contain a binding site for any known transcriptional activator. Although it is possible that some yeast activator protein fortuitously binds to our templates and stimulates transcription, we believe this possibility to be unlikely because the fragment of the $C Y C 1$ promoter used in these experiments is inactive for transcription in vivo ${ }^{10,13}$. Rather, we suppose that the basal transcription we observe results from the assembly of the basic transcription machinery without the influence of activator. Thus, we conclude that, unlike some other eukaryotic transcriptional repressors ${ }^{14-17}, \alpha 2$ does not repress transcription by interfering with activator binding or function but, rather, interferes with the assembly or activities of the general transcription machinery. Although it is possible that interference with transcriptional activators also contributes to $\alpha 2$ repression in vivo, our results indicate that it cannot be the sole mechanism. Similarly, because our transcription reactions did not include a chromatin assembly step, it seems unlikely that the effects we are observing in vitro require that the DNA be packaged as chromatin. Chromatin structure may, however, contribute to full $\alpha 2$ repression in vivo ${ }^{18-20}$. We have also addressed whether the $\alpha 2$-directed repression observed in vitro affects activated transcription. Transcription activated by a GAL4-VP16 hybrid ${ }^{21}$ ( $\lambda$ VP4) is repressed by $\alpha 2$ to about the same extent as is basal transcription (not shown).

Eukaryotic genes typically respond to several, and often many, transcriptional activator proteins. To repress transcription of such genes selectively by a mechanism that directly compromises activator function, a dedicated repressor would in principle be needed for each activator. This idea might apply, for example, to the complex regulation of the Drosophila eve gene ${ }^{15}$. In contrast, the mechanism we propose for $\alpha 2$ (and which has also been proposed for the product of the eve gene $\mathrm{e}^{22}$ ) provides a simple way to repress a gene, irrespective of the number and nature of the activator proteins that control it ${ }^{10,11}$. Because $\alpha 2$ represses transcription of many different yeast genes that are under positive control of a diverse set of activator proteins, it seems logical that such a mechanism would be observed for this protein.

Received 14 April; accepted 21 June 1994.

1. Herskowitz, I. Nature 342, 749-757 (1989).

2. Johnson, A. D. in Transcriptional Regulation 975-1006 (Cold Spring Harbor Laboratory Press, New York, 1992).

3. Keleher, C. A., Goutte, C. \& Johnson, A. D. Cell 53, 927-936 (1988).

4. Keleher, C. A., Passmore, S. \& Johnson, A. D. Molec. cell. Biol. 9, 5228-5230 (1989)

5. Passmore, S., Elbe, R. \& Tye, B.-K. Genes Dev. 3, 921-935 (1989)

6. Ammerer, G. Genes Dev. 4, 299-312 (1990).

6. Ammerer, G. Genes Dev. 4, 299-312 (1990).

7. Mukai, Y., Harashima, S. \& Oshima, Y. Molec. cell. Biol. 11, 3773-3779 (1991).

8. Williams, F. E., Varanasi, U. \& Trumbly, R. J. Molec. cell. Biol. 11, 3307-3316 (1991).
9. Keleher, C. A., Redd, M. J., Schultz, J., Carlson, M. \& Johnson, A. D. Cell 68, 709-719 Keleher, C. A., Redd, M. J., Schultz, J., Carlson, M. \& John
(1992).

10. Johnson, A. D. \& Herskowitz, I. Cell 53, 927-936 (1985).

11. Herschbach, B. H. \& Johnson, A. D. Molec. cell. Biol. 13, 4029-4038 (1993).

12. Smith, D. \& Johnson, A. Cell 68, 133-142 (1992).

13. Guarente, L., Lalonde, B., Gifford, P. \& Alani, E. Cell 36, 503-11 (1984)

14. Stanojevic, D., Hoey, T. \& Levine, M. Nature 341, 331-335 (1989)

15. Small, S., Kraut, R. Hoey, T., Warrior, R. \& Levine, M. Genes Dev. 5, 827-839 (1991).
Small, S., Blair, A. \& Levine, M. EMBO J. 11, 4047-4057 (1992).

17. Saha, S, Brickman, J. M., Lehming, N. \& Ptashne, M. Nature 363, 648-652 (1993)

18. Roth, S. Y., Dean, A. \& Simpson, R. T. Molec. cell. Biol. 10, 2247-2260 (1990)

19. Shimizu, M., Roth, S. Y., Szent-Yorgi, C. \& Simpson, R. T. EMBO J. 10, 3033-3041 (1991).

20. Roth, S. Y., Shimizu, M., Johnson, L., Grunstein, M. \& Simpson, R. T. Genes Dev. 6, 411 425 (1992).

21. Emami, K. H. \& Carey, M. EMBO J. 11, 5005-5012 (1992).

22. Johnson, F. B. \& Krasnow, M. A. Genes Dev. 6, 2177-2189 (1992).

23. Sze, J.-Y., Woontner, M., Jaehning, J. A. \& Kolhaw, G. B. Science 258, 1143-1145 (1992).

24. Wootner, M., Wade, P. A., Bonner, J. \& Jaehning, J. A. Molec. cell. Biol. 11, 4555-4560 (1991).

25. Tatchell, K., Nasmyth, K. A., Hall, B. D., Astell, C. \& Smith, M. Cell 27, 25-35 (1981).

26. Silicano, P. G. \& Tatchell, K. Cell 37, 969-978 (1984).

27. Schultz, J. \& Carlson, M. Molec. cell. Biol. 7, 3637-3645 (1987).

28. Johnson, S. thesis, Univ. Washington, Seattle (1991).

29. Sauer, R. T., Smith, D. L. \& Johnson, A. D. Genes Dev. 2, 807-816.

30. Woontner, M. \& Jaehning, J. A. J. biol. Chem. 265, 8979-8982 (1990).

ACKNOWLEDGEMENTS. We thank B. Braun, J. Brickman, M. Carey, C. Detweiler, L. Henry, K. Jarrell, K. Komachi, N. Kralli, A. Mak, E. O'Shea, M. Ptashne, M. Redd, M. Sayre, M. Schultz and $M$. Woontner for their advice and help, especially $K$. Komachi for providing the $\alpha 2^{\text {Ser10 }}$ mutant and M. J. Kelley for the help in the preparation of this manuscript.

\section{Evidence from rare gases for magma-chamber degassing of highly evolved mid-ocean-ridge basalt}

\section{David E. Flsher \& Michael R. Perfit}

Nature 343, 450-452 (1990)

IT has been drawn to our attention that the $y$-axis of Fig. 2 in this letter was mislabelled. The correct graph is shown here.

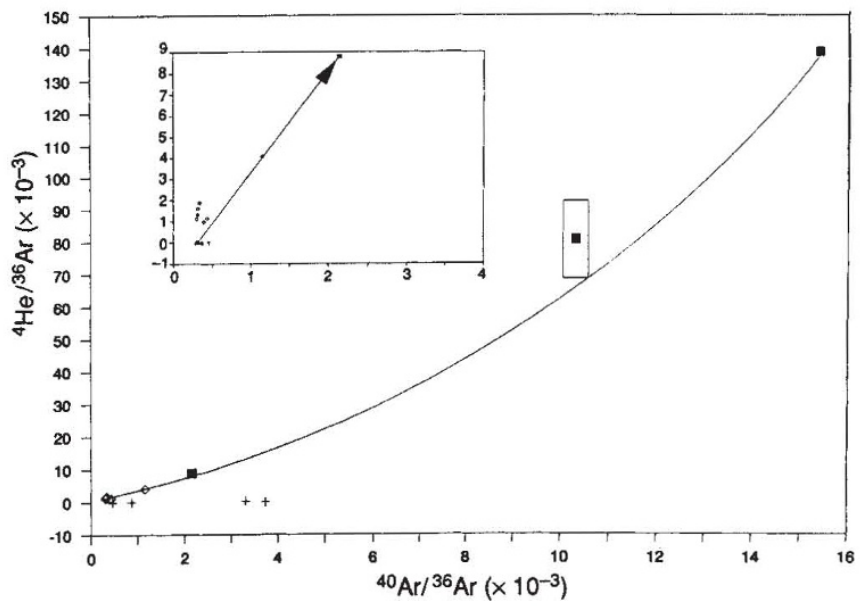

FIG. $2{ }^{4} \mathrm{He} /{ }^{36} \mathrm{Ar}$ plotted against ${ }^{40} \mathrm{Ar} /{ }^{36} \mathrm{Ar}$ for normal mid-ocean-ridge basalts (MORB) $(\mathbf{\square})$, evolved basalts $(+)$, oceanic island basalts $(\mathrm{OIB})$ $(\diamond)$, and altered non-glassy MORB $(\triangle)$. Data for OIB from refs 18,20 ; data for altered MORB from ref. 16. Insert shows in detail the region below ${ }^{40} \mathrm{Ar} /{ }^{36} \mathrm{Ar}=4,000$.

Our arguments and conclusions remain unchanged. 